\title{
ANALISIS MINAT WISATAWAN LOKAL TERHADAP TAMAN REKREASI DI TANGERANG SELATAN
}

\author{
Yustisia Kristiana ${ }^{1}$, Liana ${ }^{2}$ \\ ${ }^{1}$ Universitas Pelita Harapan, yustisia.kristiana@uph.edu \\ ${ }^{2}$ Universitas Pelita Harapan, lianaadjuddin@gmail.com
}

\begin{abstract}
ABSTRAK
Lokasi Tangerang Selatan yang strategis menciptakan peluang untuk mengembangkan daya tarik wisata yang lebih inovatif, termasuk taman rekreasi. Oleh karena itu, penelitian ini berusaha untuk memahami minat wisatawan lokal terhadap taman rekreasi di Tangerang Selatan. Data dikumpulkan dari responden menggunakan kuesioner. Teknik sampling yang akan digunakan oleh penulis adalah nonprobability sampling dengan jenis convenience sampling. Jumlah responden dalam penelitian ini adalah 300 responden. Metode analisis data adalah analisis deskriptif. Hasil penelitian menunjukkan bahwa wisatawan memiliki minat yang cukup tinggi terhadap taman rekreasi yang memiliki unsur edukasi sebagai pilihan berwisata. Taman rekreasi yang berbasis teknologi dan memiliki fasilitas yang lengkap juga memegang peran besar dalam meningkatkan pengalaman berwisata. Penelitian ini meningkatkan pemahaman tentang pengalaman berwisata di taman rekreasi, potensi bisnis taman rekreasi di masa depan, dan dapat digunakan untuk meningkatkan pariwisata di Tangerang Selatan, Provinsi Banten.
\end{abstract}

Kata kunci: daya tarik wisata, taman rekreasi, wisata edukasi

\section{ABSTRACT}

The strategic location of the South Tangerang creates opportunities to develop more innovative tourist attractions, including recreational parks. Therefore, this study seeks to understand the interest of local tourists over recreational parks in South Tangerang. Data was collected from respondents using a questionnaire. The sampling technique that will be used by the author is nonprobability sampling with the type of convenience sampling. The number of respondents in this study were 300 respondents. The method of data analysis is descriptive analysis. The study shows that tourists have a high interest in recreational parks that have an educational element as a leisure purpose. Technologybased recreational parks and complete facilities play a large role in enhancing the tourism experience. This study enhances understanding of the experiences of recreational parks, the potential of recreational parks in the future, and can be used to increase tourism in South Tangerang, Banten Province.

Keywords: tourist attraction, recreational park, edutourism

\section{PENDAHULUAN}

Indonesia sebagai destinasi memiliki keanekaragaman daya tarik wisata. Daya tarik wisata adalah sebuah sistem yang terdiri dari tiga elemen yaitu elemen wisatawan atau manusia, elemen inti atau pusat dapat berupa keistimewaan atau karakteristik daya tarik wisata dan elemen penanda atau informatif. Sebuah daya tarik wisata muncul ketika tiga elemen tersebut saling terhubung (Leiper, 1990). Daya tarik wisata yang dikunjungi oleh wisatawan dibagi menjadi tiga jenis yaitu, wisata alam, wisata budaya dan wisata buatan. Ketiga jenis daya tarik wisata tersebut memiliki keunikannya masingmasing. Menurut data Kementerian Pariwisata dalam Statistik Profil Wisatawan Mancanegara dan Wisatawan Nusantara, wisatawan mancanegara yang berkunjung ke Indonesia lebih memilih wisata budaya $(56,45 \%)$, selanjutnya wisata alam $(29,23 \%)$ dan wisata buatan $(20,25 \%)$. 
Berbeda dengan wisatawan mancanegara, wisatawan nusantara lebih memilih jenis wisata alam, selanjutnya buatan dan budaya. Pada tahun 2016 sebanyak 43,8\% wistawan nusantara memilih jenis wisata alam, 40,59\% wisata buatan dan $15,62 \%$ wisata budaya. Pada tahun 2017 sebanyak $52,66 \%$ wistawan nusantara memilih jenis wisata alam, $32,84 \%$ wisata buatan dan $14,50 \%$ wisata budaya. Dari data tersebut terlihat bahwa terjadi penurunan pada jenis daya tarik wisata buatan sebanyak $7,75 \%$.

Daya tarik wisata buatan adalah daya tarik wisata khusus, di luar wisata alam dan budaya, dapat berupa hasil kreasi. Daya tarik wisata buatan ini tidak hanya sekedar menjadi destinasi wisata saja, tetapi juga memiliki peran penting dalam membuka lapangan pekerjaan dan memberikan edukasi bagi pengunjungnya. Taman rekreasi adalah salah satu daya tarik wisata buatan yang kunjungan wisatawannya masih didominasi oleh wisatawan nusantara. Sementara, kunjungan wisatawan mancanegara masih belum bisa diperhitungkan (Prodjo, 2016).

Tangerang Selatan adalah salah satu kotamadya di Provinsi Banten yang sangat pesat perkembangannya. Hal ini dapat dilihat dari laju pertumbuhan penduduk sejak tahun 2000-2017 yang mencapai $3.53 \%$. Lokasi Tangerang Selatan yang strategis dekat dengan bandara Soekarno Hatta menjadikan Tangerang Selatan sebagai salah satu destinasi wisata. Saat ini terdapat delapan tempat rekreasi yang ada di Tangerang Selatan. Jumlah kunjungan ke daya tarik wisata unggulan seperti Ocean Park dapat mencapai 3.000 hingga 4.000 orang dalam satu harinya pada hari libur (Tohir, 2018). Sedangkan jumlah kunjungan ke Taman Wisata Pulau Situ Gintung dapat mencapai 500 orang dalam satu hari pada hari libur (Yuwanto, 2016). Oleh karena laju pertumbuhan penduduk yang baik, jumlah tempat rekreasi yang sedikit dan banyaknya jumlah kunjungan di tempat rekreasi, maka Tangerang Selatan membutuhkan taman rekreasi sebagai daya tarik wisata.

Taman rekreasi yang dikembangkan hendaknya bukan hanya berkontribusi dalam bidang pariwisata saja, tetapi juga ikut berperan dalam bidang pendidikan. Sehingga unsur edukasi sangat penting dalam pengembangan taman rekreasi.

Berdasarkan penjelasan di atas maka tujuan penelitian ini adalah untuk (1) menganalisis minat wisatawan lokal terhadap taman rekreasi di Tangerang Selatan dan (2) mengembangkan taman rekreasi sebagai pilihan daya tarik wisata di Tangerang Selatan.

\section{KAJIAN LITERATUR \\ Daya Tarik Wisata}

Menurut Ismayanti (2010), daya tarik wisata adalah usaha yang kegiatannya mengelola daya tarik wisata alam, daya tarik wisata budaya dan daya tarik wisata buatan/binaan manusia. Menurut Peraturan Pemerintah Republik Indonesia No. 50 Tahun 2011 tentang Rencana Induk Pembangunan Kepariwisataan Nasional Tahun 2010-2025, daya tarik wisata dibagi menjadi tiga jenis yaitu meliputi:

a. Daya tarik wisata alam

Daya tarik wisata alam adalah daya tarik wisata yang berupa keanekaragaman dan keunikan lingkungan alam.

b. Daya tarik wisata budaya

Daya tarik wisata budaya adalah daya tarik wisata berupa hasil olah cipta, rasa dan karsa manusia sebagai makhluk budaya.

c. Daya tarik wisata hasil buatan manusia Daya tarik wisata hasil buatan manusia adalah daya tarik wisata khusus yang merupakan kreasi artifisial (artificially created) dan kegiatan-kegiatan manusia lainnya di luar ranah wisata alam dan wisata budaya.

Taman Hiburan Tematik (Theme Park)

Taman hiburan tematik (theme park) merupakan sebuah taman rekreasi yang memiliki karakteristik khusus untuk mencirikan tempat tersebut dengan tema yang diusung dan dijadikan sebuah konsep (Imammudin, 2016). Menurut Immamudin (2016), prinsip desain yang perlu diperhatikan dalam merancang taman hiburan tematik (theme park) adalah: (1) Ketepatan, (2) Kenyamanan, (3) Keamanan, (4) Keindahan, 
Kemudahan,

Pemeliharaan.

(6) Penghijauan,

(7)

\section{Wisata Pendidikan (Edutourism)}

Wisata pendidikan (edutourism) merupakan kegiatan berkunjung ke sebuah lokasi yang memiliki nilai hiburan dan pendidikan (Winarto, 2016). Beberapa manfaat dari pelaksanaan edutourism adalah:

1. Dapat memperoleh pengalaman baru dari objek yang dilihat.

2. Dapat berpartisipasi dalam berbagai kegiatan sehingga dapat mengembangkan bakat khusus atau keterampilan,

3. Dapat memperdalam dan memperluas pengalaman.

4. Dapat menemukan kebenaran bukti teorinya atau mencobakan teorinya ke dalam praktik.

5. Dapat memperoleh pengetahuan dan pengalaman yang terintegrasi, tidak terpisah-pisah dan terpadu.

\section{METODE PENELITIAN}

Data yang dibutuhkan oleh peneliti adalah data primer dan data sekunder. Data primer digunakan untuk meneliti data responden, kondisi pasar dan minat pasar. Data sekunder digunakan untuk mendapatkan teori dan data-data pendukung. Instrumen pengumpulan data yang digunakan adalah kuesioner. Jenis kuesioner yang digunakan adalah personally administered questionnaires dan electronic and online questionnaires. Dengan menggunakan personally administered questionnaires dan electronic and online questionnaires penulis dapat mengumpulkan data dalam jumlah banyak pada waktu bersamaan.

Teknik sampling yang akan digunakan oleh penulis adalah nonprobability sampling yaitu teknik pengambilan sampel yang belum mengetahui subyek dalam penelitiannya (Sekaran dan Bougie, 2016). Jenis nonprobability sampling yang dipilih adalah convenience sampling. Convenience sampling adalah metode yang digunakan dalam memilih sampel dari elemen populasi yang datanya mudah diperoleh (Sekaran dan Bougie, 2016). Jumlah responden dalam penelitian ini adalah sebesar 300 responden. Selanjutnya data dianalisis secara deskriptif yaitu dengan cara menjelaskan dan menguraikan dengan terperinci hasil jawaban.

\section{PEMBAHASAN}

Bagian pertama dari kuesioner ini adalah profil responden. Profil responden terdiri dari enam pertanyaan yaitu, jenis kelamin, umur, status keluarga, wilayah tempat tinggal, pekerjaan dan total pengeluaran per bulan.

Tabel 1

Profil Responden

\begin{tabular}{|c|c|c|c|}
\hline \multicolumn{2}{|c|}{ Indikator } & \multirow{2}{*}{$\begin{array}{c}\begin{array}{c}\text { Jumlah } \\
\text { Responden }\end{array} \\
117 \\
\end{array}$} & \multirow{2}{*}{$\begin{array}{c}\% \\
39 \\
\end{array}$} \\
\hline Jenis & Laki-laki & & \\
\hline Kelamin & Perempuan & 183 & 61 \\
\hline \multirow{9}{*}{ Umur } & $10-14$ & & \\
\hline & Tahun & 8 & 2,7 \\
\hline & $15-19$ & & \\
\hline & Tahun & 85 & 28,3 \\
\hline & $20-24$ & & \\
\hline & Tahun & 114 & 38 \\
\hline & $25-29$ & & \\
\hline & Tahun & 15 & 5 \\
\hline & $>30$ Tahun & 78 & 26 \\
\hline \multirow{2}{*}{$\begin{array}{c}\text { Status } \\
\text { Keluarga }\end{array}$} & $\begin{array}{l}\text { Belum } \\
\text { Kawin }\end{array}$ & 220 & 73,3 \\
\hline & Kawin & 80 & 26,7 \\
\hline \multirow{11}{*}{$\begin{array}{l}\text { Wilayah } \\
\text { Tempat } \\
\text { Tinggal }\end{array}$} & Alam & & \\
\hline & Sutera & 16 & 5,3 \\
\hline & Gading & & \\
\hline & Serpong & 40 & 13,3 \\
\hline & BSD & 27 & 9 \\
\hline & Modern & & \\
\hline & Land & 9 & 3 \\
\hline & Lippo & & \\
\hline & Karawaci & 53 & 17,7 \\
\hline & Jakarta & 88 & 29,3 \\
\hline & Lainnya & 67 & 22,3 \\
\hline \multirow{6}{*}{ Pekerjaan } & Pelajar & 184 & 61,3 \\
\hline & $\begin{array}{l}\text { Pegawai } \\
\text { Negeri }\end{array}$ & 2 & 0,7 \\
\hline & $\begin{array}{l}\text { Pegawai } \\
\text { Swasta }\end{array}$ & 50 & 16,7 \\
\hline & Wiraswasta & 29 & 9,7 \\
\hline & $\begin{array}{l}\text { Ibu Rumah } \\
\text { Tangga }\end{array}$ & 27 & 9 \\
\hline & Lainnya & 8 & 2,7 \\
\hline \multirow{4}{*}{$\begin{array}{c}\text { Total } \\
\text { Pengeluaran/ } \\
\text { Bulan }\end{array}$} & $\begin{array}{l}\leq \mathrm{Rp} . \\
3.500 .000- \\
5.500 .000\end{array}$ & 200 & 66,7 \\
\hline & $\begin{array}{l}\text { Rp. } \\
5.500 .000- \\
7.500 .000\end{array}$ & 31 & 10,3 \\
\hline & $\begin{array}{l}\text { > Rp. } \\
7.500 .000- \\
9.500 .000\end{array}$ & 36 & 12 \\
\hline & > Rp. & 16 & 5,3 \\
\hline
\end{tabular}




\begin{tabular}{ccc}
\hline Indikator & $\begin{array}{c}\text { Jumlah } \\
\text { Responden }\end{array}$ & $\%$ \\
\hline $9.500 .000-$ & & \\
11.500 .000 & & \\
\hline$>$ Rp. & 17 & 5,7 \\
11.500 .000 & & \\
\hline
\end{tabular}

Sumber: Hasil olahan data (2018)

Berdasarkan tabel di atas, dapat diketahui bahwa mayoritas responden yang mengisi kuesioner berjenis kelamin perempuan yaitu sebanyak 183 responden $(61 \%)$ dan sisanya berjenis kelamin lakilaki yaitu sebanyak 117 responden (39\%). Dapat diketahui juga bahwa mayoritas responden yang mengisi kuesioner berumur 20-24 tahun dengan jumlah 114 responden (38\%). Sedangkan sebanyak 85 responden berumur $15-19$ tahun $(28,3 \%)$, sebanyak 78 responden berumur $>30$ tahun (26\%), sebanyak 15 responden berumur 25-29 tahun (5\%) dan sisanya sebanyak 8 responden berumur 10-14 tahun (2,7\%).

Mayoritas responden memiliki status belum kawin dengan jumlah sebanyak 220 responden $(73,3 \%)$ dan sisanya memiliki status kawin dengan jumlah sebanyak 80 responden $(26,7 \%)$. Dari 300 responden yang mengisi kuesioner, sebagian besar responden bertempat tinggal di Jakarta dengan jumlah sebanyak 88 responden $(29,3 \%)$, selanjutnya sebanyak 67 reponden $(22,3 \%)$ menjawab lainnya, di Lippo Karawaci dengan jumlah sebanyak 53 responden (17,7\%), di Gading Serpong dengan jumlah sebanyak 40 responden $(13,3 \%)$, di BSD dengan jumlah sebanyak 27 responden (9\%), di Alam Sutera dengan jumlah sebanyak 16 responden $(5,3 \%)$ dan di Modern Land dengan jumlah sebanyak 9 responden (3\%). Mayoritas responden bekerja sebagai pelajar/mahasiswa dengan jumlah sebanyak 184 responden $(61,3 \%)$. Sebanyak 50 responden $(16,7 \%)$ adalah pegawai swasta, sebanyak 29 responden $(9,7 \%)$ adalah wiraswasta, sebanyak 27 responden $(9 \%)$ adalah ibu rumah tangga, sebanyak 8 responden $(2,7 \%)$ menjawab lainnya dan sebanyak 2 responden $(0,7 \%)$ adalah pegawai negeri.

Profil responden yang terakhir adalah mengenai total pengeluaran per bulan. Sebanyak 200 responden $(66,7 \%)$ memiliki pengeluaran sebesar $\leq$ Rp. 3.500.000-Rp.
5.500.000 per bulan, sebanyak 36 responden (12\%) memiliki pengeluaran sebesar > Rp. 7.500.000-Rp. 9.500.000 per bulan, sebanyak 31 responden $(10,3 \%)$ memiliki pengeluaran sebesar > Rp. 5.500.000-Rp. 7.500.000 per bulan, sebanyak 17 responden $(5,7 \%)$ memiliki pengeluaran sebesar > Rp. 11.500 .000 per bulan dan sebanyak 16 responden $(5,3 \%)$ memiliki pengeluaran sebesar > Rp. 9.500.000-Rp. 11.500.000 per bulan.

Bagian selanjutnya dari kuesioner ini adalah kondisi pasar yang terdiri dari tiga pertanyaan. Ketiga pertanyaan tersebut bertujuan untuk menganalisis keadaan yang terjadi di pasar.

Tabel 2

Kondisi Pasar

\begin{tabular}{|c|c|c|c|}
\hline \multicolumn{2}{|c|}{ Indikator } & \multirow{2}{*}{$\begin{array}{c}\begin{array}{c}\text { Jumlah } \\
\text { Responden }\end{array} \\
374\end{array}$} & \multirow{2}{*}{$\begin{array}{r}\% \\
91,3\end{array}$} \\
\hline \multirow{3}{*}{$\begin{array}{l}\text { Intensitas } \\
\text { mengunjun } \\
\text { gi taman } \\
\text { rekreasi } \\
\text { dalam } 1 \\
\text { bulan }\end{array}$} & 1-2 kali & & \\
\hline & 3-4 kali & 20 & 6,7 \\
\hline & $>4$ kali & 6 & 2 \\
\hline \multirow{3}{*}{$\begin{array}{c}\text { Dengan } \\
\text { siapa } \\
\text { mengunjun } \\
\text { gi taman } \\
\text { rekreasi }\end{array}$} & Teman & 128 & 42,7 \\
\hline & Keluarga & 169 & 56,3 \\
\hline & Sendiri & 3 & 1 \\
\hline \multirow{8}{*}{$\begin{array}{c}\text { Pengeluara } \\
\text { n rata-rata } \\
\text { di taman } \\
\text { rekreasi }\end{array}$} & $\leq$ Rp. 50.000 & 22 & 7,3 \\
\hline & $>\mathrm{Rp}$ & & \\
\hline & $\begin{array}{l}50.000- \\
80.000\end{array}$ & 55 & 18,3 \\
\hline & > Rp. & 92 & 30,7 \\
\hline & 80.000- & & \\
\hline & 110.000 & & \\
\hline & $\begin{array}{l}\text { > Rp. 110- } \\
140.000\end{array}$ & 54 & 18 \\
\hline & $\begin{array}{l}>\mathrm{Rp} . \\
140.000\end{array}$ & 77 & 25,7 \\
\hline
\end{tabular}

Sumber: Hasil olahan data (2018)

Dari Tabel 2, dapat dilihat bahwa mayoritas responden mengunjungi taman rekreasi sebanyak 1-2 kali dengan jumlah 274 responden (91,3\%). Sebanyak 20 responden $(6,7 \%)$ mengunjungi taman rekreasi 3-4 kali dalam sebulan dan sebanyak 6 responden (2\%) mengunjungi taman rekreasi $>4$ kali dalam sebulan. Mayoritas responden mengunjungi taman rekreasi bersama keluarga sebanyak 169 responden $(56,3 \%)$, selanjutnya sebanyak 128 responden $(42,7 \%)$ mengunjungi taman rekreasi bersama teman dan 
sebanyak 3 responden (1\%) mengunjungi taman rekreasi sendiri. Dapat dilihat pula bahwa sebanyak 92 responden $(30,7 \%)$ melakukan pengeluaran rata-rata di taman rekreasi sebesar > Rp. 80.000-Rp. 110.000, sebanyak 77 responden $(25,7 \%)$ melakukan pengeluaran rata-rata di taman rekreasi sebesar > Rp. 140.000, sebanyak 55 responden $(18,3 \%)$ melakukan pengeluaran rata-rata di taman rekreasi sebesar > Rp. 50.000-Rp. 80.000, sebanyak 54 responden (18\%) melakukan pengeluaran rata-rata di taman rekreasi sebesar > Rp. 110.000-Rp. 140.000 dan sebanyak 22 responden $(7,3 \%)$ melakukan pengeluaran rata-rata di taman rekreasi sebesar $\leq$ Rp. 50.000 .

Kemudian terdapat pertanyaan tentang ketertarikan responden untuk mengunjungi taman rekreasi.

Tabel 3

Ketertarikan Responden Terhadap Taman

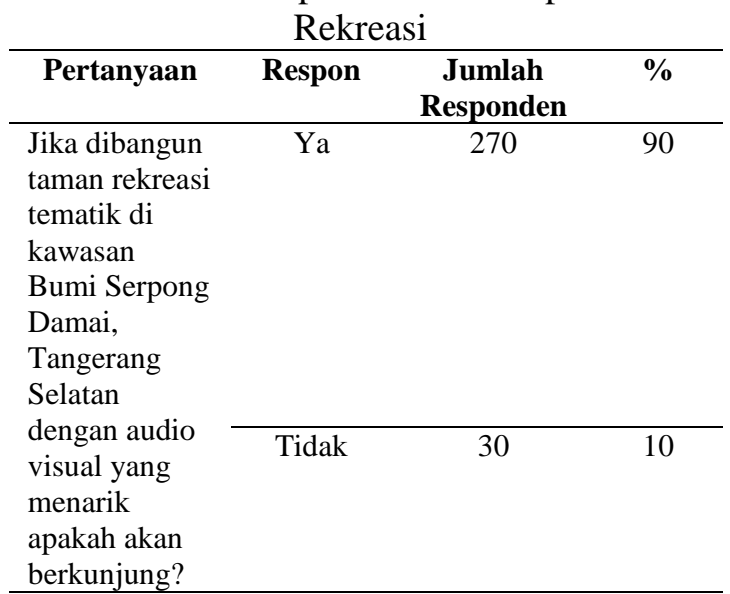

Sumber: Hasil olahan data (2018)

Berdasarkan data di atas, sebanyak 270 responden (90\%) menunjukkan ketertarikan terhadap taman rekreasi sedangkan sebanyak 30 responden $(10 \%)$ menjawab kurang tertarik.

Produk adalah berbagai fasilitas atau produk yang disediakan oleh perusahaan kepada pelanggan (Morrison, 2010). Produk yang ditawarkan oleh taman rekreasi adalah taman rekreasi yang bertema edukasi dengan audio visual yang menarik dan dilengkapi fasilitas seperti auditorium serta taman bacaan.

Tabel 4

Produk Taman Rekreasi

Pertanyaan Responden

\begin{tabular}{|c|c|c|c|}
\hline & Pilihan & Jumlah & $(\%)$ \\
\hline \multirow{9}{*}{$\begin{array}{l}\text { Taman } \\
\text { rekreasi } \\
\text { menampilkan } \\
\text { tema edukasi }\end{array}$} & Sangat & 1 & 0,3 \\
\hline & Tidak & & \\
\hline & Setuju & & \\
\hline & Tidak & 3 & 1 \\
\hline & Setuju & & \\
\hline & $\begin{array}{l}\text { Agak Tidak } \\
\text { Setuju }\end{array}$ & 14 & 4,7 \\
\hline & $\begin{array}{l}\text { Agak } \\
\text { Setuju }\end{array}$ & 58 & 19,3 \\
\hline & Setuju & 117 & 39 \\
\hline & $\begin{array}{l}\text { Sangat } \\
\text { Setuju }\end{array}$ & 107 & 35,7 \\
\hline \multirow{6}{*}{$\begin{array}{l}\text { Taman } \\
\text { rekreasi } \\
\text { menampilkan } \\
\text { audio visual } \\
\text { yang menarik }\end{array}$} & $\begin{array}{l}\text { Sangat } \\
\text { Tidak } \\
\text { Setuju }\end{array}$ & 2 & 0,7 \\
\hline & $\begin{array}{l}\text { Tidak } \\
\text { Setuju }\end{array}$ & 5 & 1,7 \\
\hline & $\begin{array}{l}\text { Agak Tidak } \\
\text { Setuju }\end{array}$ & 16 & 5,3 \\
\hline & $\begin{array}{l}\text { Agak } \\
\text { Setuju }\end{array}$ & 50 & 16,7 \\
\hline & Setuju & 97 & 32,3 \\
\hline & $\begin{array}{l}\text { Sangat } \\
\text { Setuju }\end{array}$ & 130 & 43,3 \\
\hline \multirow{6}{*}{$\begin{array}{l}\text { Terdapat } \\
\text { auditorium } \\
\text { untuk } \\
\text { menampilkan } \\
\text { film }\end{array}$} & $\begin{array}{l}\text { Sangat } \\
\text { Tidak } \\
\text { Setuju } \\
\end{array}$ & 6 & 2 \\
\hline & $\begin{array}{l}\text { Tidak } \\
\text { Setuju } \\
\end{array}$ & 7 & 2,3 \\
\hline & $\begin{array}{l}\text { Agak Tidak } \\
\text { Setuju }\end{array}$ & 18 & 6 \\
\hline & $\begin{array}{l}\text { Agak } \\
\text { Setuju }\end{array}$ & 50 & 16,7 \\
\hline & Setuju & 96 & \\
\hline & $\begin{array}{l}\text { Sangat } \\
\text { Setuju }\end{array}$ & 123 & 32 \\
\hline \multirow[t]{6}{*}{$\begin{array}{l}\text { Terdapat taman } \\
\text { bacaan }\end{array}$} & $\begin{array}{l}\text { Sangat } \\
\text { Tidak } \\
\text { Setuju }\end{array}$ & 10 & 3,3 \\
\hline & $\begin{array}{l}\text { Tidak } \\
\text { Setuju }\end{array}$ & 14 & 4,7 \\
\hline & $\begin{array}{l}\text { Agak Tidak } \\
\text { Setuju }\end{array}$ & 48 & 16 \\
\hline & $\begin{array}{l}\text { Agak } \\
\text { Setuju } \\
\end{array}$ & 65 & 21,7 \\
\hline & Setuju & 85 & 28,3 \\
\hline & $\begin{array}{l}\text { Sangat } \\
\text { Setuju }\end{array}$ & 78 & 26 \\
\hline
\end{tabular}

Sumber: Hasil olahan data (2018)

Berdasarkan Tabel 4, dapat diketahui bahwa mayoritas responden setuju terhadap taman rekreasi tema edukasi 117 responden (39\%). Sangat setuju sebanyak 107 responden $(35,7 \%)$, agak setuju sebanyak 58 responden $(19,3 \%)$, agak tidak setuju sebanyak 14 responden 
$(4,7 \%)$, tidak setuju sebanyak 3 responden (1\%) dan sangat tidak setuju sebanyak 1 responden $(0,3 \%)$.

Sebanyak 130 responden $(43,3 \%)$ sangat setuju terhadap taman rekreasi menampilkan audio visual yang menarik. Setuju sebanyak 97 responden (32,3\%), agak setuju sebanyak 50 responden $(16,7 \%)$, agak tidak setuju sebanyak 16 responden $(5,3 \%)$, tidak setuju sebanyak 5 responden $(1,7 \%)$ dan sangat tidak setuju sebanyak 2 responden $(0,7 \%)$.

Mayoritas responden sangat setuju terhadap terdapat auditorium kecil untuk menampilkan film sebanyak 123 responden $(41 \%)$. Setuju sebanyak 96 responden (32\%), agak setuju sebanyak 50 responden $(16,7 \%)$, agak tidak setuju sebanyak 18 responden (6\%), tidak setuju sebanyak 7 responden $(2,3 \%)$ dan sangat tidak setuju sebanyak 6 responden $(2 \%)$.

Sedangkan terhadap terdapat taman bacaan mayoritas responden setuju sebanyak 85 responden $(28,3 \%)$. Sangat setuju sebanyak 78 responden (26\%), agak setuju sebanyak 65 responden $(21,7 \%)$, agak tidak setuju sebanyak 48 responden $(16 \%)$, tidak setuju sebanyak 14 responden $(4,7 \%)$ dan sangat tidak setuju sebanyak 10 responden $(3,3 \%)$. Dengan demikian dapat disimpulkan bahwa mayoritas responden memiliki tanggapan yang positif terhadap produk yang akan disediakan oleh taman rekreasi.

Tabel 5

Mean/rata-rata hasil pertanyaan yang diajukan

\begin{tabular}{lllll}
\hline No. & Deskripsi & Mean & $\begin{array}{c}\text { Std. } \\
\text { Deviation }\end{array}$ & N \\
\hline 1 & Taman & 5,03 & 0,939 & 300 \\
& $\begin{array}{l}\text { rekreasi } \\
\text { menampilkan } \\
\text { tema edukasi }\end{array}$ & & & \\
& Taman & 5,08 & 1,033 & 300 \\
& rekreasi \\
menampilkan & & & \\
& $\begin{array}{l}\text { audio visual } \\
\text { yang menarik }\end{array}$ & & & \\
\hline 3 & $\begin{array}{l}\text { Terdapat } \\
\text { auditorium } \\
\text { untuk } \\
\text { menampilkan } \\
\text { film }\end{array}$ & & 1,97 & 300 \\
& & & \\
\hline 4 & $\begin{array}{l}\text { Terdapat } \\
\text { taman bacaan }\end{array}$ & 4,45 & 1,332 & 300 \\
\hline
\end{tabular}

Sumber: Hasil olahan data (2018)
Tabel 5 menunjukkan bahwa mean ratarata di angka 5 yang menunjukkan bahwa responden memahami pertanyaan yang diajukan.

Berdasarkan hasil di atas dapat dianalisis bahwa target pasar utama dari taman rekreasi adalah perempuan sedangkan target pasar sekundernya adalah laki-laki. Oleh karena itu perempuan dapat mendorong laki-laki untuk mengunjungi taman rekreasi. Mayoritas responden berada di kelompok umur 20-24 tahun dengan status keluarga belum menikah. Hasil ini akan memengaruhi program dan aktivitas yang akan dikembangkan di taman rekreasi.

Untuk wilayah tempat tinggal, mayoritas responden berasal dari Jakarta. Hal ini menunjukkan bahwa responden dari Jakarta memerlukan adanya pilihan daya tarik wisata untuk berwisata, dan dari segi akses dapat mudah dijangkau. Mayoritas responden adalah pelajar/mahasiswa dengan total pengeluaran per bulan sebesar $\leq$ Rp. 3.500.000-Rp. 5.500.000. Hasil ini menunjukkan bahwa mayoritas responden termasuk dalam golongan ekonomi kelas menengah.

Mayoritas responden memiliki intensitas mengunjungi taman rekreasi dalam 1 bulan sebanyak 1-2 kali dan bersama dengan keluarga. Hal ini mengindikasikan bahwa responden akan berwisata ke taman rekreasi bersama dengan keluarga, sebagai wahana untuk edukasi. Kristiutami (2017) menyatakan bahwa keputusan berkujung ke daya tarik wisata berpengaruh positif dan signifikan terhadap kepuasan wisatawan. Keputusan berkunjung didapat melalui proses pertimbangan berbagai aspek. Ketika keputusan untuk berkunjung telah dibuat oleh seorang wisatawan, keputusan tersebut merupakan keputusan matang dimana daya tarik wisata yang dipilih merupakan daya tarik wisata yang mampu memberikan kepuasan terhadap kegiatan berwisata wisatawan.

Untuk rata-rata pengeluaran di taman rekreasi, mayoritas responden menunjukkan bahwa dapat mengeluarkan hingga maksimum Rp. 110.000. Responden menyadari bahwa kualitas yang baik dan konsep yang menarik akan 
meningkatkan tingkat pembelian. Hal ini mendukung pernyataan Oliver (1980) bahwa kualitas layanan yang diterima oleh pelanggan memengaruhi perilaku pelanggan. Salah satu hal yang dapat dilakukan adalah price collaboration, dimana harga yang ditawarkan akan lebih kompetitif dengan diikuti kualitas layanan lebih baik, sehingga akan menimbulkan daya tarik bagi pelanggan.

Berdasarkan pernyataan produk yang telah disiapkan, responden menyetujui produk yang ditawarkan oleh taman rekreasi. Hal ini akan memengaruhi penjualan dan mengembangkan lebih banyak inovasi untuk mendorong kunjungan dari wisatawan. Kotler dan Keller (2011) menyatakan bahwa pelanggan menginginkan produk yang menawarkan kualitas, kinerja atau fitur inovatif terbaik yang dapat memberikan kepuasan kepada konsumen. Produk dengan tema edukasi yang memanfaatkan teknologi dan memiliki desain menarik akan meningkatkan minat wisatawan untuk berkunjung ke taman rekreasi.

\section{PENUTUP}

Penelitian ini dilakukan untuk mengetahui hubungan minat masyarakat, dalam hal ini adalah wisatawan lokal, terhadap taman rekreasi yang telah ada dan potensial yang baru akan dibuka. Berdasarkan penelitian yang telah dilakukan melalui kuesioner, dapat disimpulkan bahwa tingkat minat masyarakat terhadap taman rekreasi cukup tinggi. Taman rekreasi yang akan didirikan mendapat apresiasi dari masyarakat dan tentunya menunjukkan kebutuhan dari masyarakat akan daya tarik wisata dengan tema pendidikan dalam konteks taman rekreasi.

Perlu dilakukan penelitian lebih lanjut apakah pengembangan taman rekreasi yang berbasis teknologi akan memengaruhi kunjungan wisatawan ke taman rekreasi. Hal ini akan berguna untuk pengembangan pariwisata di Provinsi Banten secara umum, dan Tangerang Selatan secara khusus.

\section{REFERENSI}

Immammudin, Ahmad Haritz (2016). Taman Hiburan Tematik (Theme Parks) di Yogyakarta. Yogyakarta: Universitas Atma Jaya.

Ismayanti (2010). Pengantar Pariwisata. Jakarta: PT Gramedia Widisarana Indonesia.

Kotler, P. T. dan Keller, K. L. (2011) Marketing Management, $14^{\text {th }} \mathrm{ed}$. New Jersey: Pearson.

Kristiutami, Y. P. (2017). Pengaruh Keputusan Berkunjung Terhadap Kepuasan Wisatawan di Museum Geologi Bandung. Jurnal Pariwisata, Vol. 4(1), 53-61.

Leiper, N. (1990). Tourist attraction systems. Annals development: An analysis of the positive and of Tourism Research, 17(2), 367-384.

Morrison, Alastair M. (2010). Hospitality \& Travel Marketing Fourth Edition. USA: Delmar.

Oliver, R. L. (1980). A Cognitive Model of the Antecedents and Consequences of Satisfaction Decisions. Journal of Marketing Research, Vol. 17(4), 460-469.

Peraturan Pemerintah, Nomor 50 Tahun 2011 Tentang Rencana Induk Pembangunan Kepariwisataan Nasional Tahun 2010-2025.

Prodjo, Wahyu Adityo (1 Juli 2016). Kunjungan Taman Rekreasi Indonesia Masih Didominasi Wisnus. Kompas. Diakses dari https://travel.kompas.com/read/201 6/07/01/060900727/Kunjungan.Ta man.Rekreasi.Indonesia.Masih.Did ominasi.Wisnus

Tohir, Jaisy Rahman (29 Desember 2018). Pengunjung Ocean Park Capai 3.000 Setiap Hari Libur, Tsumani Tak Berpengaruh. Tribunnews. Diakses dari http://jakarta.tribunnews.com/2018/ 12/29/pengunjung-ocean-parkcapai-3000-setiap-hari-liburtsunami-tak-berpengaruh\#gref

Sekaran, U., \& Bougie, R. (2016). Ressearch Methods for Business. United Kingdom: John Wiley \& Sons. 
Winarto (2016). Pengembangan Model Wisata Pendidikan Berbasis Kearifan Lokal dengan Pendekatan Saintifik di Brebes Selatan Sebagai Alternatif Model Belajar Siswa Sekolah Dasar. Brebes: Dialetika.

Yuwanto, Endro (4 Mei 2016). Situ Gintung Pun Menanti Pengunjung. Republika. Diakses dari https://republika.co.id/berita/koran/ urbana/16/05/04/o6n7k68-situgintung-pun-menanti-pengunjung

\section{BIODATA PENULIS}

Yustisia Kristiana, menempuh pendidikan Manajemen Kepariwisataan di Sekolah
Tinggi Pariwisata Bandung (1996) lalu melanjutkan pada program Magister Manajemen, Universitas Pelita Harapan (2007). Saat ini menjabat sebagai Ketua Program Studi Usaha Perjalanan Wisata Fakultas Pariwisata Universitas Pelita Harapan. Aktif menulis artikel di berbagai jurnal ilmiah dan menjadi narasumber dalam berbagai seminar.

Liana, menempuh pendidikan Sarjana Terapan Pariwisata di Universitas Pelita Harapan program studi Usaha Perjalanan Wisata (2015). Pernah melakukan Industrial Job Training di Rotama Tour, Bali (2017). 